Original Article

\title{
Anadenanthera colubrina (Fabaceae) logs in the Atlantic Forest biome: first host plant for Thoracibidion lineatocolle (Col.: Cerambycidae) and a new host for Temnopis megacephala (Col.: Cerambycidae)
}

\author{
Troncos de Anadenanthera colubrina (Fabaceae) no bioma da Mata Atlântica: primeira \\ planta hospedeira de Thoracibidion lineatocolle (Col.: Cerambycidae) e uma nova planta \\ hospedeira para Temnopis megacephala (Col.: Cerambycidae)
}

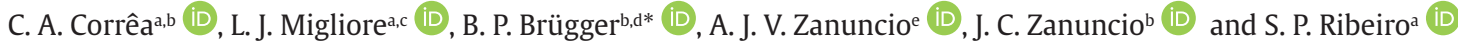 \\ a Universidade Federal de Ouro Preto - UFOP, Núcleo de Pesquisas em Ciências Biológicas - NUPEB, Laboratório de Ecologia do Adoecimento e \\ Florestas - LEAF, Ouro Preto, MG, Brasil \\ ${ }^{\mathrm{b}}$ Universidade Federal de Viçosa - UFV, Departamento de Entomologia/BIOAGRO, Laboratório de Controle Biológico de Insetos - LCBI, Viçosa, \\ MG, Brasil \\ ' Universidade de São Paulo - USP, Departamento de Entomologia - MZUSP, Laboratório de Coleoptera, São Paulo, SP, Brasil \\ ¿Universidade Federal de Juiz de Fora - UFJF, Laboratório de Ecologia Comportamental e Bioacústica - LABEC, Juiz de Fora, MG, Brasil \\ e Universidade Federal de Viçosa - UFV, Departamento de Engenharia Florestal - DEF, Viçosa, MG, Brasil
}

\begin{abstract}
Wood-boring beetles develop in live trees and dead wood, performing ecological services such as decomposition and regulation of forest resources. Species of the Cerambycidae family, widely distributed in the world, bore into the trunks of trees and dead wood in native and cultivated areas. The objective is to report the first host plant for Thoracibidion lineatocolle (Thomson, 1865) (Coleoptera: Cerambycidae) and a new host plant for Temnopis megacephala (Germar, 1824) (Coleoptera: Cerambycidae) in the Brazilian Atlantic Forest biome. Three logs, with one-meter-long by $20 \mathrm{~cm}$ in diameter, were cut from the trunk of a healthy Anadenanthera colubrina (Fabaceae) tree in October 2013 and tied in the understory at 1.5m high in the Rio Doce State Park, Minas Gerais State, Brazil. The logs, exposed in the forest, were each removed after 40, 80 and 120 days and stored individually in a cardboard box in the "Laboratório de Campo do Projeto de Ecologia de Longa Duração (PELD-CNPq)" in the Rio Doce State Park. A total of 94 individuals of $T$. lineatocolle and 228 of T. megacephala emerged from the A. colubrina logs. This is the first report of a host plant for T. lineatocolle and a new host plant for T. megacephala.
\end{abstract}

Keywords: Cerambycidae, host tree, Rio Doce State Park, saproxylic insects.

\section{Resumo}

Besouros broqueadores se desenvolvem em árvores vivas e madeira morta, realizando serviços ecológicos como decomposição e regulação de recursos da floresta. Espécies da família Cerambycidae, amplamente distribuídas no mundo, perfuram o caule de árvores e madeira morta em áreas nativas e cultivadas. O objetivo é relatar a primeira planta hospedeira de Thoracibidion lineatocolle (Thomson, 1865) (Coleoptera: Cerambycidae) e uma nova planta hospedeira para Temnopis megacephala (Germar, 1824) (Coleoptera: Cerambycidae) no bioma da Mata Atlântica brasileira. Três toras, com um metro de comprimento por $20 \mathrm{~cm}$ de diâmetro, foram cortadas de uma árvore sadia de Anadenanthera colubrina (Fabaceae) em outubro de 2013 e amarradas no sub-bosque a 1,5m de altura no Parque Estadual do Rio Doce, estado de Minas Gerais, Brasil. As toras, expostas na floresta, foram removidas, cada uma, após 40, 80 e 120 dias e armazenadas, individualmente, em caixas de papelão no "Laboratório de Campo do Projeto de Ecologia de Longa Duração (PELD-CNPq)" no Parque Estadual do Rio Doce. Um total de 94 indivíduos de T. lineatocolle e 228 de T. megacephala emergiu das toras de A. colubrina. Esse é o primeiro registro de uma planta hospedeira para T. lineatocolle e o de uma nova planta hospedeira para T. megacephala.

Palavras-chave: Cerambycidae, árvore hospedeira, Parque Estadual do Rio Doce, insetos saproxílicos.

*e-mail: brunopb2002@yahooo.com.br

Received: June 25, 2020 - Accepted: September 2, 2020 
The Atlantic Forest biome has a high biodiversity (Rocha et al., 2005; Colombo and Joly, 2010), which results in several ecosystem services (Alho, 2008). Wood-boring beetles colonize living trees and dead wood, where their larvae form galleries as they develop (Silva Neto et al., 2011; Ferreira-Filho et al., 2014; Fujihara et al., 2020). The activity of these insects favors ecological services such as decomposition (Ulyshen et al., 2016) and regulation of forest resources (Seaton et al., 2015; Pereira and Ferreira, 2017). The Cerambycidae family (Insecta: Coleoptera), widely distributed in the world and with high diversity in the tropics (Wang, 2017), colonizes tree species in different forest strata (Lee et al., 2014; Li et al., 2017). These insects bore into tree branches, trunks and roots (Wang, 2017) in native (Lee et al., 2014; Li et al., 2017) and cultivated areas (Zanuncio et al., 2009; Ferreira-Filho et al., 2014).

Anadenanthera colubrina (Vell.) Brenan (Fabaceae), pioneer to initial secondary tree in dry tropical forests, occurs in Argentina and Brazil, with heights of up to 30 meters and more than $23 \mathrm{~cm}$ in diameter (Carvalho, 2002; Nunes et al., 2007). The A. colubrina wood is suitable for charcoal production, fences, firewood, houses, and the handicraft manufacturing, mainly in rural communities (Monteiro et al., 2006).

The objective is to report the first host plant for Thoracibidion lineatocolle (Thomson, 1865) (Coleoptera: Cerambycidae) and a new host plant for Temnopis megacephala (Germar, 1824) in the Brazilian Atlantic Forest biome.

The study was carried out in the Rio Doce State Park, an Atlantic Forest remnant in the Minas Gerais State, southeast Brazil (19 46' 48.36" S and 42 36'02.93" W) (Carvalho and Ribeiro, 2018). The area has 36,000 ha with 44 natural lakes and, predominantly, composed of semidecidual forest (Costa e Silva, 2001; Fonseca-Silva et al., 2015). This area has a tropical humid mesothermic climate, with well-defined dry and rainy seasons (Antunes, 1986).

A healthy Anadenanthera colubrina (Fabaceae) tree was cut down and three logs with one-meter-long by $20 \mathrm{~cm}$ in diameter were cut from its trunk in October 2013 (rainy season) in a secondary forest area of the Rio Doce State Park, Atlantic Forest biome, Brazil. The logs were tied with light spinning as a rope and placed in the forest understory at $1.5 \mathrm{~m}$ from the ground. The logs were removed from the forest after 40, 80 and 120 days (one each time) and stored in an individual cardboard box in the field laboratory. Each cardboard box had two transparent plastic jars, with one on each side, as a source of light to attract adults that emerged from the wood. These boxes were opened monthly, when the adult beetles were collected and the logs were wetted and placed back into the boxes. Inspections were carried out on each log until February 2015, when all boxes were opened and the material was discarded.

A total of 94 and 228 individuals of $T$. lineatocolle and T. megacephala, respectively, was collected (Figure 1), with distinct temporal distribution (Table 1). The wood-boring beetle succession in the logs can explain this temporal colonization pattern, since certain species depends on previous colonization by others to invade the $\log$ (CalderónCortés et al., 2011; Victorsson, 2012).

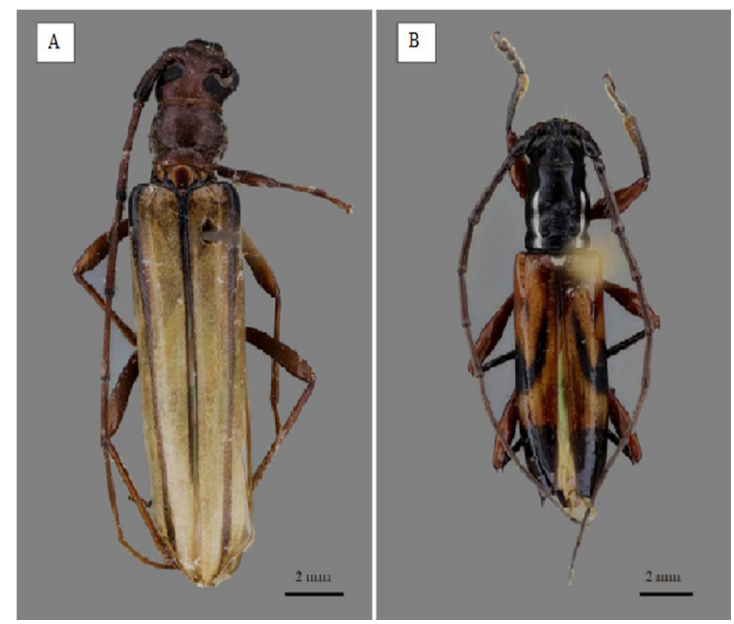

Figure 1. Temnopis megacephala (A) and Thoracibidion lineatocolle (B) (Coleoptera: Cerambycidae) adults emerged from Anadenanthera colubrina (Fabaceae) logs harvested in the Atlantic Forest biome.

Table 1. Number of Temnopis megacephala and Thoracibidion lineatocolle (Coleoptera: Cerambycidae) adults emerged from Anadenanthera colubrina (Fabaceae) logs at different exposure times in the Atlantic Forest biome

\begin{tabular}{lcc}
\hline Days & $\begin{array}{c}\text { Temnopis } \\
\text { megacephala }\end{array}$ & $\begin{array}{c}\text { Thoracibidion } \\
\text { lineatecolle }\end{array}$ \\
\hline 40 & 205 & 11 \\
80 & 22 & 68 \\
120 & 1 & 15 \\
\hline
\end{tabular}

The occurrence of $T$. lineatocolle in A. colubrina logs represents the first record of a host plant for this beetle. Thoracibidion lineatocolle occurs in Argentina, Brazil (Bahia, Espírito Santo, Maranhão, Minas Gerais, Paraná, Rio de Janeiro, Rio Grande do Sul, Santa Catarina and São Paulo States) and Paraguay (Monné, 2019).

A new host plant, A. colubrina, is now registered for $T$. megacephala, a normally abundant beetle (Maia et al., 2003), reported in Argentina, Brazil (Alagoas, Bahia, Ceará, Espírito Santo, Goiás, Minas Gerais, Paraná, Rio de Janeiro, Rio Grande do Norte, Rio Grande do Sul, Santa Catarina, São Paulo and Sergipe States) and Paraguay (Maia et al., 2003; Monné, 2019). This beetle colonized Acacia melanoxylon R.Br. (Fabaceae) branches girdled by Oncideres sp. (Di Iorio, 1994) and non-girdled ones of Acacia decurrens Willd., Piptadenia sp. (Fabaceae) and Miconia sellowiana Naudin (Melastomataceae) (Monné, 2019).

The knowledge about $T$. lineatocolle and T. megacephala life history is scarce, since the studies focus mainly on passive collections, with light (Nascimento et al., 2017; Corrêa et al., 2020) and malaise (Guedes et al., 2019) traps, wood colonization (Di Iorio, 1994; Corrêa et al., 2020) reviewing material deposited in the museums (Martins, 1971). Consequently, more studies are needed to better understand the life history of these species. 
The record of Thoracibidion lineatocolle and Temnopis megacephala in fresh-cut Anadenanthera colubrina logs, presented here, expands the knowledge of the life history for these boring insects, with new host tree information.

\section{Acknowledgements}

The authors acknowledge the Brazilian agencies "Conselho Nacional de Desenvolvimento Cientifico e Tecnológico (CNPq), Coordenação de Aperfeiçoamento de Pessoal de Nível Superior (CAPES/PELD- Finance Code 001), Fundação de Amparo à Pesquisa do Estado de Minas Gerais (FAPEMIG)" and "Programa Cooperativo sobre Proteção Florestal (PROTEF) do Instituto de Pesquisas e Estudos Florestais (IPEF)" for scholarships and financial support. JCZ and SPR are granted researcher from CNPq.

\section{References}

ALHO, C.J.R., 2008. The value of biodiversity. Brazilian Journal of Biology = Revista Brasileira de Biologia, vol. 68, no. 4, suppl., pp. 1115-1118. http://dx.doi.org/10.1590/S151969842008000500018. PMid:19197481.

ANTUNES, F.Z., 1986. Caracterização climática do Estado de MG. Informe Agropecuário, vol. 12, pp. 1-13.

CALDERÓN-CORTÉS, N., QUESADA, M. and ESCALERA-VÁZQUEZ, L.H., 2011. Insects as trunks engineers: interactions mediated by the twig-girdler Oncideres albomarginata chamela enhance arthropod diversity. PLoS ONE, vol. 6, no. 4, pp. e19083. http:// dx.doi.org/10.1371/journal.pone.0019083. PMid:21526161.

CARVALHO, B. and RIBEIRO, S.P., 2018. Architecture of Mabea fistulifera Mart. (Euphorbiaceae), a neotropical semideciduous tree: development and variations in crown allometry between environments. Flora, vol. 239, pp. 104-110. http://dx.doi. org/10.1016/j.flora.2017.12.003.

CARVALHO, P.E.R., 2002. Angico-Branco. Colombo: Embrapa Florestas, 10 p. Circular Técnica.

COLOMBO, A.F. and JOLY, C.A., 2010. Brazilian Atlantic Forest latu sensu: the most ancient Brazilian forest, and a biodiversity hotspot, is highly threatened by climate change. Brazilian Journal of Biology = Revista Brasileira de Biologia, vol. 70, no. 3, suppl., pp. 697-708. http://dx.doi.org/10.1590/S1519-69842010000400002. PMid:21085776.

CORRÊA, C.A., MIGLIORE, L.J., GARBELINI, L., ZANUNCIO, J.C. and RIBEIRO, S.P., 2020. Species survey of the subfamily Cerambycinae (Coleoptera: Cerambycidae) in the Rio Doce State Park, Minas Gerais, Brazil. Zootaxa, vol. 4881, no. 2, pp. 323-336. https://doi.org/10.11646/zootaxa.4881.2.6.

COSTA E SILVA, L.V., 2001 [viewed 9 February 2020]. Diagnóstico da cobertura vegetal: contribuição ao Plano de Manejo [online]. Belo Horizonte: Instituto Estadual de Florestas. Available from: http://www.ief.mg.gov.br/index2.php?option=com content\&do_pdf=1\&id=306

DI IORIO, O.R., 1994. Cerambycidae y otros Coleoptera emergidos de ramas cortadas por Oncideres germari (Lamiinae: Onciderini) en el norte argentino. Revista de Biología Tropical, vol. 42, pp. 649-661.

FERREIRA-FILHO, P.J., WILCKEN, C.F., GUERREIRO, J.C., LIMA, A.C., CARMO, J.B. and ZANUNCIO, J.C., 2014. First record of the wood-borer Hylettus seniculus (Coleoptera: Cerambycidae) in Pinus caribaea var. hondurensis plantations in Brazil. The Florida Entomologist, vol. 97, no. 4, pp. 1838-1841. http://dx.doi. org/10.1653/024.097.0462.

FONSECA-SILVA, F.M., CARVALHO, M.A. and RIBEIRO, S.P., 2015. Caracterização da matéria orgânica particulada dos últimos 10 mil anos a partir de um testemunho do Parque Estadual do Rio Doce, MG, Brasil: implicações paleoambientais. Revista Brasileira de Paleontologia, vol. 18, no. 1, pp. 161-170. http:// dx.doi.org/10.4072/rbp.2015.1.11.

FUJIHARA, R.T., VIANI, R.A.G. and SAVARIS, M., 2020. First record of Trachyderes succinctus succinctus (Linnaeus, 1758) (Coleoptera: Cerambycidae) in Khaya ivorensis A. Chev. (Meliaceae) in Brazil. Brazilian Journal of Biology = Revista Brasileira de Biologia. http:// dx.doi.org/10.1590/1519-6984.226537. PMid:32215449.

GUEDES, R.S., ZANELLA, F.C.V. and GROSSI, P.C., 2019. Composição e riqueza de espécies de uma comunidade de Coleoptera (Insecta) na Caatinga. Iheringia. Série Zoologia, vol. 109, pp. e2019012. http://dx.doi.org/10.1590/1678-4766e2019012.

LEE, C.J., BAXT, A., CASTILLO, S. and BERKOV, A., 2014. Stratification in French Guiana: cerambycid beetles go up when rains come down. Biotropica, vol. 46, no. 3, pp. 302-311. http://dx.doi. org/10.1111/btp.12101.

LI, L., AGUILAR, R. and BERKOV, A., 2017. What shapes cerambycid beetle communities in a tropical forest mosaic? Assessing the effects of host tree identity, forest structure, and vertical stratification. Biotropica, vol. 49, no. 5, pp. 675-684. http:// dx.doi.org/10.1111/btp.12432.

MAIA, A.C., IANNUZZI, L., NOBRE, C.E.B. and ALBUQUERQUE, C.M., 2003. Padrões locais de diversidade de Cerambycidae (Insecta, Coleoptera) em vegetação de Caatinga. In: I.R. LEAL, M. TABARELLI and J.M.C. SILVA, eds. Ecologia e conservação da Caatinga. Editora Universitária da UFPE, pp. 391-433.

MARTINS, U.R., 1971. Notas sobre Cerambycinae (Coleoptera, Cerambycidae) VI: subsídios ao conhecimento dos Ibidionini. Arquivos de Zoologia, vol. 21, no. 3, pp. 121-178. http://dx.doi. org/10.11606/issn.2176-7793.v21i3p121-178.

MONNÉ, M.A., 2019. Catalogue of the Cerambycidae (Coleoptera) of the neotropical region. Part I: subfamily Cerambycinae. Rio de Janeiro: Museu Nacional, Universidade Federal do Rio de Janeiro.

MONTEIRO, J.M., ALMEIDA, C.F.C.B.R., ALBUQUERQUE, U.P., LUCENA, R.F.P., FLORENTINO, A.T.N. and OLIVEIRA, R.L.C., 2006. Use and traditional management of Anadenanthera colubrina (Vell.) Brenan in the semi-arid region of northeastern Brazil. Journal of Ethnobiology and Ethnomedicine, vol. 2, no. 1, pp. 1-7. http:// dx.doi.org/10.1186/1746-4269-2-6. PMid:16420708.

NASCIMENTO, F.E.L., MERMUDES, J.R.M., BRAVO, F. and SANTOSSILVA, A., 2017. Checklist, new species and new records of Cerambycidae (Insecta: Coleoptera) from Chapada Diamantina, Bahia state, Brazil.Zootaxa, vol. 4232, no. 3, pp. 347-360. http:// dx.doi.org/10.11646/zootaxa.4232.3.4. PMid:28264366.

NUNES, S.R.D.F.S., GARCIA, F.C.P., LIMA, H.C.D. and CARVALHOOKANO, R.M.D., 2007. Mimosoideae (Leguminosae) arbóreas do Parque Estadual do Rio Doce, Minas Gerais, Brasil: distribuição geográfica e similaridade florística na floresta atlântica no sudeste do Brasil. Rodriguésia, vol. 58, no. 2, pp. 403-421. http:// dx.doi.org/10.1590/2175-7860200758215.

PEREIRA, S.A. and FERREIRA, S.A.N., 2017. Fruit and seed biometry and seedling morphology of Parkia discolor (Spruce ex Benth.). Revista Árvore, vol. 41, no. 2, pp. e410206. http://dx.doi. org/10.1590/1806-90882017000200006.

ROCHA, C.F.D., VAN SLUYS, M., BERGALLO, H.G. and ALVES, M.A.S., 2005. Endemic and threatened tetrapods in the restingas of the 
biodiversity corridors of Serra do Mar and of the central da Mata Atlântica in eastern Brazil. Brazilian Journal of Biology = Revista Brasileira de Biologia, vol. 65, no. 1, pp. 159-168. http://dx.doi. org/10.1590/S1519-69842005000100019. PMid:16025914.

SEATON, S., MATUSICK, G., RUTHROF, K.X. and HARDY, G.E.S.J., 2015 Outbreak of Phoracantha semipunctata in response to severe drought in a mediterranean Eucalyptus forest. Forests, vol. 6 , no. 12, pp. 3868-3881. http://dx.doi.org/10.3390/f6113868.

SILVA NETO, A.J.D., TREVISAN, H., NASCIMENTO, L.S.D. and CARVALHO, A.G.D., 2011. Descrição de danos e volume de fitomassa lenhosa de fustes de Cassia siamea Lam. seccionados por Coccoderus novempunctatus (Coleoptera: Cerambycidae). Revista Árvore, vol. 35, no. 4, pp. 801-807. http://dx.doi. org/10.1590/S0100-67622011000500005.

ULYSHEN, M.D., MÜLLER, J. and SEIBOLD, S., 2016. Bark coverage and insects influence wood decomposition: direct and indirect effects. Applied Soil Ecology, vol. 105, pp. 25-30. http://dx.doi. org/10.1016/j.apsoil.2016.03.017.

VICTORSSON, J., 2012. Semi-field experiments investigating facilitation: arrival order decides the interrelationship between two saproxylic beetle species. Ecological Entomology, vol. 37, no. 5, pp. 395-401. http://dx.doi.org/10.1111/j.1365-2311.2012.01377.x.

WANG, Q., 2017. Cerambycidae of the world: biology and pest management. Boca Raton: CRC Press, 628 p. http://dx.doi. org/10.1201/b21851.

ZANUNCIO, J.C., PIRES, E.M., ALMADO, R.P., ZANETTI, R., MONNÉ, M.A., PEREIRA, J.M. and SERRÃO, J.E., 2009. Damage assessment and host plant records of Oxymerus basalis (Dalman, 1823) (Cerambycidae: Cerambycinae: Trachyderini) in Brazil. Coleopterists Bulletin, vol. 63, no. 2, pp. 179-181. http://dx.doi. org/10.1649/0010-065X-63.2.179. 